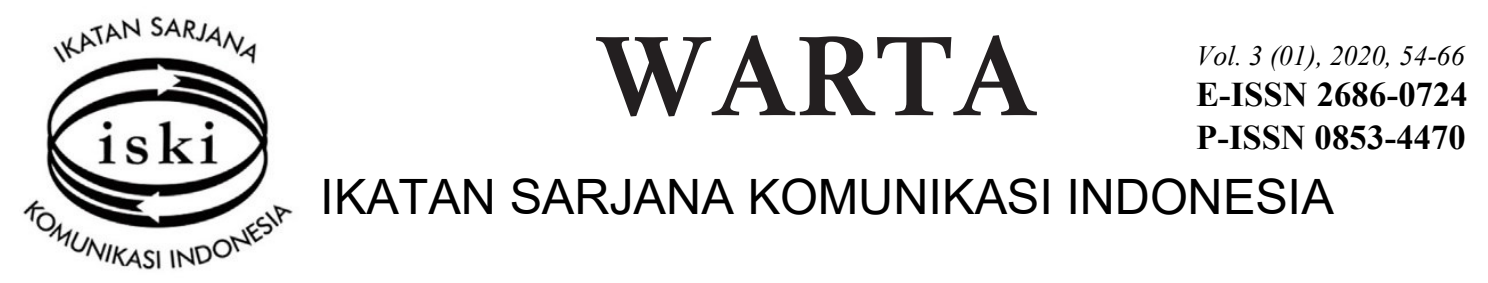

\title{
Komunikasi Politik Identitas K.H. Ma'ruf Amin sebagai Strategi Depolarisasi Agama pada Kontestasi Demokrasi Pilpres 2019
}

\author{
http://dx.doi.org/10.25008/wartaiski.v3i01.46
}

\author{
Saeful Mujab ${ }^{1^{*}}$ Azhar Irfansyah $^{2}$ \\ 1,2Fakultas Ilmu Komunikasi Universitas Bhayangkara Jakarta Raya \\ J1. Perjuangan No.81, Marga Mulya, Kota Bekasi 17143 - Indonesia \\ *e-mail korespondensi: saeful.mujab@dsn.ubharajaya.ac.id
}

Submitted: 13/04/2020, Revised: 05/05/2020, Accepted: 03/06/2020

Accredited by Kemristekdikti No. 30/E/KPT/2019

\begin{abstract}
When incumbent President Joko Widodo announced K.H. Ma'ruf Amin as his running mate in the 2019 presidential election, a big question arose as to whether the elderly, traditional, and low-profile leader would be able to answer the political dynamics in Indonesia. It turns out that the personal branding of K.H. Ma'ruf Amin is the reason for Joko Widodo to pick him in the presidential election. Brand discussions have been offered by Lilleker and Jackson as well as Busby and Cronshaw. Lilleker and Jackson highlighted the challenges posed by personal branding for traditional parties, while Busby and Cronshaw explored possibilities it opens up for new forms of political mobilization and participation branding. One of the essential elements of political communication is political actors. Personal branding is among the steps of political actors. Dengan demikian, menjadi penting menguak komunikasi politik identitas Ma'ruf Amin pada kontestasi demokrasi Pilpres 2019. Thus, it is important to uncover the political communication of K.H. Ma'ruf Amin's identity in the democratic contestation of the 2019 presidential election in Indonesia. This study which uses the fundamental research method of literature review, aims to see whether or not the political communication of K.H. Ma'ruf Amin's identity is able to draw sympathy in the face of political participation branding 212 in the 2019 presidential and vice-presidential election. The results of the study show that the personal branding of Ma'ruf Amin, as a Muslim figure, was unable to attract sympathy in the face of the Islam-based political participation branding.
\end{abstract}

Keywords: Branding; democratic contestation; identity politics; political communication; political depolarization

\begin{abstract}
Abstrak
Ketika Joko Widodo mengumumkan K.H Ma'ruf Amin menjadi pendampingnya sebagai calon wakil presiden pada pilpres 2019, muncul pertanyaan apakah pemimpin berusia lanjut, tradisional, dan lowprofile mampu menjawab dinamika politik yang sedang terjadi di Indonesia. Ternyata personal branding Ma'ruf Amin menjadi alasan bagi Joko Widodo untuk memilihnya. Diskusi brand ditawarkan oleh Lilleker dan Jackson serta Busby dan Cronshaw. Lilleker dan Jackson menyoroti tantangan yang ditimbulkan personal branding bagi partai-partai tradisional, sedangkan Busby dan Cronshaw mengeksplorasi kemungkinan yang terbuka untuk bentuk-bentuk baru mobilisasi politik dan branding partisipasi. Salah satu unsur penting dalam komunikasi politik adalah aktor politik. Di antara langkah aktor politik adalah personal branding. Dengan demikian, menjadi penting menguak komunikasi politik identitas Ma'ruf Amin pada kontestasi demokrasi Pilpres 2019. Dengan menggunakan metode penelitian fundamental literature riview, penelitian ini bertujuan untuk mengetahui mampu tidaknya komunikasi politik identitas Ma'ruf Amin menarik simpati di hadapan branding partisipasi politik 212 pada pemilihan presiden dan wakil presiden 2019. Hasil penelitian menunjukkan, personal branding Ma'ruf Amin sebagai tokoh Islam ternyata belum mampu menarik simpati di hadapan branding partisipasi politik 212 yang berbasis Islam. Kata kunci: Branding; depolarisasi politik; identitas politik; komunikasi politik;, kontestasi politik
\end{abstract}




\section{PENDAHULUAN}

Penelitian ini berusaha mengungkapkan strategi komunikasi politik dalam Pemilihan Umum Presiden (Pilpres) 2019. Dari dua pasang calon presiden dan wakil presiden, Joko Widodo-K.H. Ma'ruf Amin versus Prabowo-Sandiaga Uno, sosok K.H. Ma'ruf Amin adalah sosok pilihan yang menarik. K.H. Ma'aruf Amin berasal dari latar belakang Islam yang kuat, pernah menjadi Ketua Majelis Ulama Indonesia (MUI), dan Rais Am Syuriyah (Dewan Penasehat) Nahdlatul Ulama. Kedua hal tersebut, menjadikannya menjadi sebuah pilihan di tengah meningkatnya arus Islam dalam politik Indonesia.

Apabila pilihan itu merupakan upaya memenangkan pertarungan Pilpres, maka menjadi penting menyoroti aspek komunikasi politik yang dilakukannya. Strategi komunikasi politik, terutama memobilisasi identitas agama bukanlah hal yang baru. Meski begitu, seperti dapat dilihat dalam Pilpres Amerika Serikat, Presiden Donald Trump terpilih, salah satunya, berkat dukungan kelompok Kristen Evangelis (Katie, 2019). Besarnya dukungan kelompok agama tertentu berpengaruh langsung terhadap hasil pemilihan. Sebagai negara dengan penduduk Islam terbesar di dunia, bukan tidak mungkin kemenangan Pilpres juga ditentukan berhasil-tidaknya para calon menjaring suara dari kelompok Islam.

Dalam studi komunikasi politik, diskusi brand telah ditawarkan oleh Lilleker dan Jackson serta Busby dan Cronshaw yang menyoroti pentingnya bentuk-bentuk baru media sosial untuk memahami brand politik. Lilleker menyoroti tantangan yang ditimbulkannya bagi partai-partai tradisional, sedangkan Busby dan Cronshaw mengeksplorasi kemungkinan yang terbuka untuk bentuk-bentuk baru mobilisasi politik dan branding partisipasi (Needham \& Smith, 2015).

Dalam konteks politik Indonesia, penyelenggaraan Pemilu 2019 tidak bisa dilepaskan dari mobilisasi politik dan branding partisipasi gerakan Islamis yang berawal dari protes terhadap Basuki Tjahaja Purnama alias Ahok, Gubernur DKI Jakarta yang dianggap menista Islam. Mobilisasi massa besar-besaran pada 2 Desember 2016 tidak berhenti setelah tuntutan memenjarakan Ahok berhasil. Aksi massa ini dilembagakan menjadi Persaudaraan Alumni 212 dengan Novel Bamukmin sebagai ketuanya. Aksi massa ini juga menginspirasi reuni 212 yang bergulir hingga Desember 2018, bahkan menginspirasi terbentuknya waralaba toko swalayan 212 Mart.

Di balik mobilisasi politik dan branding partisipasi 212 terjadi polarisasi yang tidak dapat dielakkan, lantaran basis dari mobilisasi politik dan partisipasi branding gerakan 212 ini adalah Islam yang nilai-nilainya lekat dalam keseharian masyarakat Indonesia, sehingga dampak polarisasinya semakin dalam. Muncul sentimen menyamakan pihak yang menetang agenda gerakan 212 sebagai kelompok anti-Islam. Penampakan paling vulgar dari setimen ini adalah pemasangan spanduk menolak menyolatkan jenazah pendukung Ahok di beberapa masjid di Jakarta Selatan pada 2017 (Ahmad, 2017).

Kelompok Islamis hendak mengulangi kembali keberhasilan merebut kursi pemerintahan gubernur Jakarta dengan menggunakan Islam sebagai kartu truf (Alexander 2018). Hanya kali ini sasarannya adalah kursi kepresidenan. Banyak kalangan menilai berlanjutnya reuni 212 setelah penangkapan Ahok menunjukkan bahwa dipenjarakannya Ahok hanyalah sasaran antara, sedangkan sasaran akhirnya adalah istana kepresidenan (Reuni 212: Relevansi gerakan dan upaya menggenjot suara Prabowo, 2018).

Di tengah sengkarut seperti itu, Joko Widodo (Jokowi) mendeklarasikan Ma'ruf Amin sebagai pasangan cawapresnya pada Pemilihan Umum Presiden dan Wakil Presiden 2019. Ma'ruf Amin sendiri bukan wajah asing bagi kalangan Islamis dan gerakan 212. Ia memegang posisi sentral di MUI yang mendakwa Ahok menista agama. Ma'ruf Amin juga turut membentuk gerakan 212 (Felicia, 2018).

Personal branding Ma'ruf Amin sebagai penyandang gelar Kiai yang telah malang melintang dalam urusan keislaman, tampilannya sebagai sesepuh, selalu berpeci dan bersarung, latar belakangnya dari Nahdhatul Ulama barangkali dapat memuluskan jalan Jokowi dalam merangkul umat Islam. Pilihan Jokowi itu disambut baik oleh PBNU. Namun posisi Ma'ruf Amin yang pernah ikut mendirikan gerakan 212 tak ayal memicu debat di kalangan pendukung Jokowi, sampai-sampai muncul pertanyaan apakah Ma'ruf Amin merupakan berkah atau beban dalam kampanye Jokowi. Bahkan menurut Charta Politika, Ma'ruf Amin hanya difungsikan sebagai bemper politik untuk meredam serangan kelompok Islamis terhadap petahana dan sebagai penjaring suara umat Islam khususnya dari kalangan NU (Anwar, 2018).

Kelompok Islamis yang bergabung dalam gerakan 212 juga nampaknya belum beralih dari posisi mereka untuk melengserkan Jokowi dari istana. Penelitian dari CSIS menjelaskan, jajaran pimpinan gerakan 212 dengan jelas menyatakan keberpihakan mereka kepada Prabowo (Arya, 2018). Oleh karena itu menarik untuk dikaji lebih jauh, seberapa kuat personal branding Ma'ruf Amin sebagai tokoh Islam di hadapan branding partisipasi politik 212 pada pemilihan presiden dan wakil presiden 2019. 
Salah satu unsur penting dalam komunikasi politik adalah aktor politik dan langkah aktor politik adalah menjual personal branding kepada masyarakat. Dengan demikian, menjadi penting menguak lebih jauh hal tersebut. Terkait dengan itu, maka penelitian ini bertujuan memperdalam pemahaman mengenai personal branding Ma'ruf Amin sebagai tokoh Islam. Apakah personal branding-nya mampu menarik simpati di hadapan branding partisipasi politik 212 untuk mendulang keberhasilan pada Kontestasi Demokrasi Pilpres 2019 di Indonesia.

\section{KERANGKA TEORI}

Komunikasi politik merupakan sebuah bidang kajian keilmuan yang terus berkembang. Meskipun kelahirannya sudah berlangsung beberapa abad yang lalu, namun komunikasi politik terus menyesuikan dan mengikuti perkembangan zaman, sehingga menjadi model ilmu lintas disiplin yang selalu terbarukan (Miller \& McKerrow, 2010). Sejarah kemunculan ilmu komunikasi politik sebagai bidang lintas-disiplin dimulai tahun 1956. Proses intervensi berkaitan dengan kepemimpinan politik, struktur kelompok yang pengaruh politiknya dimobilisasi dan ditransmisikan lembaga pemerintahan formal dan perilaku memilih warga (Miller \& McKerrow, 2010).

Nimmo mendefinisikan komunikasi politik adalah komunikasi (aktivitas) politis berdasarkan konsekuensinya (aktual atau potensial) yang mengatur perilaku manusia di bawah kondisi konflik (Nimmo Dan, Rakhmat, \& Surjaman, 2005). Komunikasi politik juga didefinisikan sebagai suatu ilmu yang mempelajari dan menelaah perilaku dan kegiatan komunikasi bersifat politik, berakibat politik, serta memiliki pengaruh terhadap perilaku politik (Alwi, 1990). McNair menegaskan, komunikasi politik sebagai diskusi tentang alokasi sumber daya publik (pendapatan), otoritas resmi (yang diberi wewenang membuat keputusan hukum, legislatif dan eksekutif), serta sanksi resmi (apa yang diberikan penghargaan atau dihukum oleh negara) (McNair, 2011).

Komunikasi Politik sebagai sebuah kajian terus menyesuikan dan mengikuti perkembangan zaman, selalu di-redefine oleh berbagai ahli, salah satunya Crozier dengan merumuskan bahwa komunikasi politik dipandang sebagai media atau saluran informasi dan persuasi, disampaikan dan dipertukarkan. Pesan hanya ditransfer dari pengirim ke penerima dengan anggapan bahwa arti "makna" pengirim tetap relatif utuh.

Asimetri dan distorsi yang signifikan dalam pertukaran ini dianggap sebagai gejala patologi propaganda. Formulasi ini bekerja dengan jenis logika linier, menafsirkan komunikasi dalam "hal-hal" yang terpisah, diperdagangkan secara sepihak antara identitas yang berbeda dari sini ke sana (Crozier, 2007). Kemudian ditambahkan, komunikasi politik merupakan bentuk pemerintahan rekursif (suatu bentuk pemerintahan yang beroperasi sesuai dengan logika informasi generatif) yang menempatkan upaya-upaya untuk menjelaskan kecenderungan, terutama dalam pengumpulan kehidupan dan proses politik, baik dengan pola pikir hubungan masyarakat atau logika media (Crozier, 2007).

\section{Politik Identitas}

Bennett menyebut politik identitas sebagai sebuah "gerakan sosial baru" yang muncul setelah tahun 1960-an, berpusat pada identitas kelompok (perempuan, minoritas, imigran, dan penduduk asli) atau menyebabkan masalah antinuklir, konservasi lingkungan, dan hak-hak khusus (Bennett, 2012). Perkembangannya kemudian, melebur dengan mobilisasi lebih heterogen dengan serangkaian penyebab seperti keadilan ekonomi (perdagangan yang adil, ketimpangan, dan pembangunan), perlindungan lingkungan, dan perang, serta perdamaian yang diarahkan untuk memindahkan target dari lokal ke nasional dan transnasional dan dari pemerintah ke bisnis (Bennett, 2012).

Semakin beragam mobilisasi, ekspresi lebih personal sering terjadi, biasanya melibatkan teknologi komunikasi yang memungkinkan individu mengaktifkan jaringan sosial mereka yang terikat secara longgar. Masih banyak politik konvensional yang didasarkan pada identifikasi dengan partai, ideologi, dan sebab-sebab umum. Namun, kebangkitan politik yang lebih personal telah menjadi tren menonjol (Bennett, 2012).

Berbeda dengan Bennet, Syafii Ma'arif menegaskan, jika dilihat dari rentang waktu, isu politik identitas baru dikaji oleh para ilmuwan sosial pada 1970-an di Amerika Serikat. Hal itu berlangsung ketika menghadapi masalah minoritas, jender, feminisme, ras, etnisitas, dan kelompok-kelompok sosial 
lainnya yang merasa terpinggirkan, dan teraniaya (Syafii, 2010). Kemudian cakupan politik identitas meluas pada ikatan-ikatan kultural yang beragam, problem keagamaan, dan kepercayaan (Syafii, 2010).

Politik identitas di Indonesia lebih terkait pada masalah yang berkaitan dengan kelompok sosial dalam sistem sosial atau kebudayaan yang mempunyai arti atau kedudukan tertentu karena keturunan, agama, adat, dan Bahasa. Selanjutnya terkait dengan agama, juga ideologi, dan kepentingankepentingan lokal yang diwakili oleh para elit pada umumnya dengan artikulasinya masing-masing.

Salah satu wujud dari politik identitas adalah gerakan pemekaran daerah. Isu-isu tentang keadilan dan pembangunan daerah menjadi sangat sentral, namun apakah semuanya tulus atau lebih banyak dipengaruhi oleh ambisi dan keinginan para elit lokal untuk tampil sebagai penguasa, merupakan masalah yang tidak selalu mudah dijelaskan (Syafii, 2010).

Kemudian muncul sebuah pertanyaan, siapa yang memiliki ide pertama kali sehingga istilah politik identitas itu tercipta? Hingga sekarang belum terjawab. Namun secara substantif, politik identitas dapat dikaitkan dengan adanya kepentingan para anggota suatu kelompok sosial yang merasa ditekan dan tersingkir oleh dominasi mayoritas dalam sebuah bangsa atau negara (Abdullah, 2017).

Ubed menegaskan, politik identitas merupakan kajian politik yang terfokus pada permasalahan yang menyangkut perbedaan-perbedaan yang didasarkan atas asumsi-asumsi fisik tubuh (Ubed, 2002). Masalah-masalah tersebut mencakup persoalan politik yang dimunculkan sebagai akibat dari persoalanpersoalan gender, feminisme, maskulinisme, problematika politik etnis yang secara mendasar berbeda fisik, dan pertentangan-pertentangan yang dimunculkannya, atau persoalan-persoalan politik karena perbedaan agama, kepercayaan, dan bahasa dalam situasi yang fundamental, multikultural, dan multi etnis (Ubed, 2002).

Cukup menarik berbicara mengenai persoalan-persoalan politik karena perbedaan agama, karena akan tercipta politik identitas agama. Sebagaimana diketahui, politik identitas berkenaan dengan agama, selalu hidup dalam arena politik di bumi pertiwi. Momentum beberapa pemilihan kepala daerah telah memberikan contoh nyata bagi pembenaran argumentasi bahwa identitas agama, muncul menjadi sebuah kekuatan politik.

Sari berpendapat, politik identitas agama merupakan proses konstruksi seperti pandangan Frederick Barth. Barth memandang, identitas agama sebagai hasil dari proses yang kompleks manakala batas-batas simbolik terus dibangun oleh manfaat mitologi suatu hitungan sejarah untuk kepentingan situasional para elit politik (Sari, 2016). Pada tahap selanjutnya, konstruksi identitas agama kemudian digunakan sebagai proses instrumentalisme. Tujuannya adalah sebagai alat untuk manipulasi dan mobilisasi sosial demi mengukuhkan atribut-atribut agama sebagai alat kekuasaan (Sari, 2016).

\section{Branding}

Dalam literatur manajemen kontemporer, branding dipandang sebagai aspek penting identitas yang berakar dalam hubungan sosial (Marsh \& Fawcett, 2011). Mars mengutip McDivitt (2003), branding bukan hanya pengidentifikasi atau label. Branding awalnya dapat dilihat sebagai benih, sehingga perlu dirancang, diposisikan, dan didorong untuk tumbuh. Mars juga mengutip Basu dan Wang (2009) yang menegaskan branding merupakan proses menciptakan identitas untuk suatu produk; dengan kata lain, menciptakan ekuitas konsumen danberkontribusi pada penyerapan produk yang lebih besar di pasar (Marsh \& Fawcett, 2011).

Saat ini, branding adalah kegiatan inti dari sebuah sistem kapitalisme, sehingga harus dimasukkan dalam upaya serius untuk memahami masyarakat dan politik kontemporer. Namun, terlepas dari signifikansi sosialnya, branding jarang menjadi subjek pemeriksaan empiris bersama dan pengembangan teori di luar sekolah bisnis.

Selanjutnya dalam personal branding, proses terstruktur membangun merek sebanding dengan meluncurkan merek produk baru, dan personal branding melakukan hal yang sama untuk orang-orang seperti yang dilakukan pemasar untuk produk (Marsh \& Fawcett, 2011).

\section{Personal Branding dalam Politik}

Marsh berpendapat personal branding adalah beragam aktivitas individu untuk diketahui di pasar. Hughes mendefinisikan personal branding sebagai cara untuk mengidentifikasi barang atau jasa dari satu penjual, atau kelompok penjual, dan untuk membedakan mereka dari pesaing dengan menghadirkan seseorang, sebuah nama, istilah, tanda, simbol atau desain, atau kombinasi dari semuanya (Hughes, 2007). 
Berbeda dengan Hughes, Bernardes mengemukakan personal branding adalah sintesis dari semua harapan, gambaran, dan persepsi yang diciptakannya di benak orang lain ketika mereka melihat atau mendengar nama Anda (Bernardez, 2007). Selanjutnya personal branding menurut Jhonson merupakan proses seseorang secara aktif mencoba mengelola kesan orang lain tentang keterampilan, kemampuan, dan pengalaman mereka (Johnson, 2017).

Personal branding sangat menonjol dalam pemasaran politik. Pemimpin suatu partai adalah personal branding dan diperuntukkan sebagai bagian dari strategi co-branding atau branding individu. Hal ini merupakan fenomena yang lebih modern, karena di masa lalu pemimpin lebih merupakan bagian dari merek partai dan karena itu bertindak sebagai lebih dari pendukung selebriti untuk merek partai. Namun seiring perkembangan, partai politik menyadari bahwa seorang pemimpin adalah penanda yang sangat baik bagi pemilih, atau konstituen dari perubahan arah partai dan dengan demikian semakin banyak penekanan pada pemimpin menjadi personal branding (Hughes, 2007).

Selanjutnya Isfahani berpendapat menciptakan brand yang kuat tidak mudah. Dibutuhkan pengetahuan bagaimana cara membuat keuntungan yang baik, sehingga mampu bersaing dan memberikan keberhasilan organisasi. Personal brand juga menentukan keberhasilan seorang, sehingga dapat disimpulkan personal brand adalah popularitas seorang untuk orang lain atau nilai-nilai, perilaku dan karakteristik yang orang lain sadari dalam diri seseorang (Isfahani, Aghdaie, \& Homaei, 2011).

Banyak saluran tersedia di media sosial untuk menyampaikan brand pribadi seseorang seperti LinkedIn, Pinterest, Instagram, Facebook, Vimeo, YouTube dan blog (Caulfield, 2005). Beberapa kandidat dan partai politik telah fokus pada media sosial, seperti terjadi dan berkembang pesat di Inggris. Brand partai politik dan brand kandidat dikembangkan dalam domain interaktif, termasuk Facebook, Twitter, dan YouTube (Needham \& Smith, 2015). Termasuk keberhasilan kampanye Obama dalam menggunakan komunikasi online untuk mempromosikan dirinya sebagai pemuda, teknologi tinggi, dan responsive. Partai-partai secara bertahap melepaskan cengkeraman di ruang online mereka yang pada periode sebelumnya ditandai dengan penegasan kembali hierarkis, karakteristik komunikasi satu arah dari media offline (Needham \& Smith, 2015).

Brand partai politik sangat dipengaruhi oleh pemimpin besar partai politik dengan kebijakan dan nada komunikasi yang dibentuk oleh media massa. Interaktivitas online menarik bagi orang yang sudah tertarik dengan politik. Selanjutnya branding mungkin lebih relevan dalam kaitannya dengan kandidat perorangan yang dapat mengembangkan reputasi lokal karena dapat diakses oleh konstituen dan berhubungan dengan masalah dunia nyata. Dalam hal ini teknologi baru dapat menjadi salah satu dari sejumlah pengaruh yang cenderung ke arah pemilihan yang lebih berpusat pada kandidat (Needham \& Smith, 2015).

Lilleker \& Jackson, dan Busby \& Cronshaw menekankan pentingnya bentuk-bentuk baru media sosial untuk memahami brand politik. Jaringan dan komunitas online yang difasilitasi oleh Facebook, Twitter, dan YouTube membuatnya lebih sulit dari sebelumnya bagi pihak dan perusahaan untuk mengontrol merek mereka, membawa tuntutan baru untuk interaktivitas dan memberikan peluang baru bagi konsumen atau pemilih untuk membentuk brand (Needham \& Smith, 2015).

\section{Polarisasi}

Polarisasi adalah hasil dari perubahan pendapat dalam arah posisi ingroup (Friedkin, 1999). Selanjutnya menurut Kerr, "Polarisasi adalah kecenderungan ke arah posisi yang ekstrem. Polarisasi merupakan proses, perbuatan, penyinaran, magnetisasi, kecenderungan pembagian atas dua bagian yang berlawanan dan ekstrem. Pergeseran yang penuh resiko, suatu subset gejala pergeseran pilihan yang mengundang polarisasi kelompok (Kerr, 1992)”.

Polarisasi kelompok terjadi ketika pergeseran pilihan dalam arah yang sama dengan opini awal rata-rata (misalnya, jika pada beberapa masalah, sikap awal anggota rata-rata adalah positif/negatif, maka sikap selanjutnya dari anggota rata-rata setelah diskusi kelompok akan lebih positif/negatif) (Friedkin, 1999). Penjelasan tentang pergeseran pilihan adalah mendasar karena itu akan menjelaskan polarisasi kelompok. Polarisasi kelompok selalu melibatkan pilihan bergeser, tetapi pergeseran pilihan dapat terjadi tidak memerlukan polarisasi kelompok (misal, pilihan pergeseran yang berlawanan arah dari kecenderungan awal kelompok) (Friedkin, 1999).

Friedkin menerapkan teori tersebut pada pergeseran pilihan dan polarisasi dalam kelompokkelompok kecil dan menunjukkan bagaimana teori ini dapat menginformasikan dan mengintegrasikan kerja sebelumnya. Ia menunjukkan (1) pergeseran pilihan dapat timbul hanya dari ketidaksetaraan 
dalam pengaruh relatif orang dalam interaksi kelompok, (2) ketidaksetaraan tersebut merupakan bagian dari proses pengaruh interpersonal, dan (3) polarisasi kelompok bukan fitur independen dalam proses pembentukan opini dalam diskusi kelompok tentang berbagai masalah. Perubahan pilihan adalah produk dari struktur sosial kelompok di mana anggota tertentu memiliki pengaruh lebih dari yang lain selama proses pembentukan pendapat (Friedkin, 1999)

Selanjutnya McGarty berargumen polarisasi adalah orang-orang menyesuaikan diri dengan norma bersama dalam kelompok, tetapi norma bukanlah rata-rata pra-tes melainkan posisi yang paling prototipe dari kelompok. Prototipikalitas anggota dalam kelompok didefinisikan dengan menggunakan prinsip meta-kontras: semakin sedikit seseorang berbeda dari anggota dalam kelompok dan semakin dia berbeda dari anggota kelompok luar, semakin representatif dia dari dalam kelompok.

Jadi prototipe adalah posisi yang paling baik mendefinisikan apa yang dimiliki oleh kelompok berbeda dengan kelompok yang relevan. Orang dengan rasio kontras meta tertinggi (diperoleh dengan membagi perbedaan rata-rata seseorang dari anggota kelompok keluar dengan perbedaan rata-rata dari anggota dalam kelompok) memegang posisi paling suka sama suka.

Dengan demikian, posisi normatif yang paling prototipikal tidak perlu menjadi yang paling mirip dengan posisi dalam kelompok lainnya (posisi rata-rata, yang rata-rata paling tidak berbeda dari posisi dalam-kelompok lainnya), karena posisi yang kurang mirip mungkin berbeda lebih jauh dari yang lain, kontras keluar-kelompok. Posisi yang paling konsensual dan normatif dipahami sebagai properti kategorikal yang menentukan kelompok sebelum interaksi dan sebagai posisi di mana anggota bertemu melalui interaksi sosial (McGarty, Turner, Hogg, David, \& Wetherell, 1992).

\section{METODE PENELITIAN}

Metode penelitan yang digunakan dalam penelitian ini adalah metode kepustakaan (library research). Fokus penelitian kepustakaan dilakukan untuk menemukan berbagai teori, hukum, dalil, prinsip, atau gagasan yang digunakan untuk menganalisis dan memecahkan pertanyaan penelitian yang dirumuskan. Adapun sifat dari penelitian ini adalah analisis deskriptif, yakni penguraian secara teratur data yang diperoleh, kemudian diberi pemahaman dan penjelasan agar dapat dipahami dengan baik.

Data yang digunakan pada penelitian ini adalah data sekunder yang diperoleh bukan dari pengamatan langsung, tetapi diperoleh dari hasil penelitian peneliti-peneliti terdahulu. Sumber data sekunder pada penelitian ini berupa buku-buku dan jurnal-jurnal ilmiah berkenaan dengan politik identitas dan personal branding. Pengumpulan data dilakukan dengan mencari atau menggali data dari literatur yang terkait dengan rumusan masalah. Selanjutnya data yang telah diperoleh dari berbagai sumber dikumpulkan menjadi suatu kesatuan dokumen yang diperuntukkan untuk menjawab permasalahan yang telah dirumuskan.

Penelitian ini menggunakan analisis anotasi bibliografi untuk menganalisa data. Anotasi berarti kesimpulan sederhana dari suatu artikel, buku, jurnal, atau beberapa sumber tulisan yang lain, sedangkan bibliografi merupakan daftar sumber dari suatu topik (Mentari 2014). Dari kedua definisi tersebut, anotasi bibliografi diartikan sebagai daftar sumber-sumber yang digunakan dalam suatu penelitian, yang pada setiap sumbernya diberikan simpulan terkait dengan apa yang tertulis di dalamnya.

Penelitian ini menggunakan empat prosedur yakni, (1) organize, yakni mengorganisasi literatur yang akan ditinjau. Literatur yang di-review merupakan literatur yang sesuai dengan permasalahan. Adapun tahap dalam mengorganisasi literatur adalah mencari ide, tujuan umum, dan simpulan dari literatur dengan membaca abstrak, paragraf pendahuluan dan kesimpulan, serta mengelompokkan literatur berdasarkan kategori-kategori tertentu (Mentari 2014); (2) synthesize, yakni menyatukan hasil organisasi literatur menjadi suatu ringkasan agar menjadi satu kesatuan yang padu dengan mencari keterkaitan antarliteratur; (3) identify, yakni mengidentifikasi isu-isu kontroversi dalam literatur. Isu kontroversi yang dimaksud adalah isu penting untuk dianalisis, guna mendapatkan suatu tulisan yang menarik untuk dibaca; dan (4) formulate, yakni merumuskan pertanyaan yang membutuhkan penelitian lebih lanjut (Mentari 2014).

\section{HASIL PENELITIAN}

K.H. Ma'ruf Amin merupakan seorang ulama yang pernah menjabat Ketua Umum MUI, Pengurus Besar Nahdlatul 'Ulama (PBNU). Nama lengkapnya adalah Prof. DR. Kiai Haji Ma'ruf Amin, lahir di Tangerang, 1 Agustus 1943 (Wink, 2018). Ma'ruf Amin menikah dengan Siti Huriyah yang 
juga berasal dari keluarga ulama tahun 1963 (Wink, 2018). Dari pernikahan ini Ma'ruf Amin dikaruniai dua anak: Siti Haniatunnisa, dan Siti Makrifah. Pada tahun 2013, Siti Huriyah wafat, lalu dia menikah dengan Wury Estu Handayani tahun 2014 (Wink, 2018).

Masa kecil Ma'ruf Amin dihabiskan di Desa Kresek, Tangerang. Pagi dia belajar di sekolah dasar sorenya mengaji di madrasah ibtidaiah. Sempat belajar agama selama beberapa bulan di Pesantren Citangkil, Cilegon, Banten milik K.H. Syam'un Alwiah (Wink, 2018). Pada usia 12 tahun Ma'ruf belajar di Pondok Pesantren Tebu Ireng, Jombang, Jawa Timur. Pesantren itu banyak melahirkan tokohtokoh ulama besar dari kalangan NU. Pendidikannya di pesantren Tebu Ireng dimulai dari dasar. Selesai dari Gontor, ia melanjutkan pendidikan di SMA Muhammadiyah, Jakarta namun tidak selesai dan kembali ke Banten mendalami agama Islam di berbagai pondok: Pesantren Caringin, Labuan; Pesantren Petir, Serang, dan Pesantren Pelamunan, Serang-Banten (Wink, 2018).

Setelah menikah dengan Siti Churiyah, Ma'ruf pindah ke Jakarta Utara serta melanjutkan Pendidikan di Fakultas Ushuludin Universitas Ibnu Khaldun, Bogor. Mar'uf aktif di Gerakan Pemuda (GP) Ansor Jakarta dan menjadi ketua di tahun 1964. Berbekal pengalaman ketua GP Ansor Jakarta, karirnya di politik menanjak dengan menjadi anggota Dewan Perakilan Rakyat Daerah Daerah Khusus Ibukota Jakarta dari Fraksi Golongan Islam pada Pemilu 1971. Pada1989, Ma'ruf Amin menjadi Khatib Aam Syuriah PBNU setelah Mukhtamar NU di Pesantren Krapyak (Wink, 2018).

Pasca lengsernya Presiden Soeharto tahun 1998, Ma'ruf menjabat Ketua Tim Lima yang dibentuk PBNU yang melahirkan Partai Kebangkitan Bangsa (PKB). Setelah PKB berdiri, ia terpilih sebagai anggota Majelis Permusyawaratan Rakyat Republik Indonesia mewakili PKB. Ma'ruf juga pernah menjadi Ketua Komisi VI Dewan Perwakilan Rakyat dari PKB. Setelah K.H. Abdurahman Wahid lengser dari jabatan Presiden RI, Ma'ruf lebih banyak menghabiskan aktifitasnya di MUI dengan tugas memberi fatwa seputar ekonomi syariah di tingkat nasional.

Salah satu capaian terbesarnya di dunia ekonomi syariah adalah menjadi pencetus Dewan Syariah Nasional (DSN) di bawah naungan MUI yang dibentuk tahun 1999. Pembentukan lembaga itu tidak lepas dari peran dan inisiasi Ma'ruf sebagai ahli ekonomi syariah. Karena peran aktif dan ide-idenya yang orisinal, ia kemudian dipercaya menjadi Ketua Badan Pelaksana Harian DSN MUI. Selama memimpin DSN, ia sangat produktif mengeluarkan fatwa sebagai pegangan umat Islam dalam aktivitas ekonomi (Lemonjake, 2019). Menurut buku karyanya, "Penggerak Umat Pengayom Bangsa (2018)", total fatwa yang telah dikeluarkan DSN berjumlah 116, setiap tahun rata-rata mengeluarkan enam sampai dengan delapan fatwa.

Presiden Susilo Bambang Yudhoyono menunjuknya sebagai Anggota Dewan Pertimbangan Presiden (Lemonjake, 2019). Pengalamannya yang banyak di bidang agama dan politik mengantarkan Ma ruf Amin menjadi Rais 'Aam PBNU dari tahun 2015 hingga 2020. Selain itu Ma'ruf juga menjabat sebagai Ketua MUI Pusat dari tahun 2015-2019 (Lemonjake, 2019).

Ma'ruf tidak pernah mengenyam pendidikan magister hingga doktor dalam pendidikan formal, namun pengetahuannya yang luas tentang agama dan memiliki berbagai karya akademis mengantarkannya mendapat gelar Doktor Honoris Causa (Dr HC) dari Universitas Islam Negeri (UIN) Syarif Hidayatullah Jakarta (Zaenal, 2012), dan gelar profesor bidang Hukum Ekonomi Islam dari UIN Maulana Malik Ibrahim Malang. Ma'ruf dikukuhkan sebagai guru besar bidang ilmu ekonomi muamalat syariah berdasarkan Keputusan Menteri Riset, Teknologi, dan Pendidikan Tinggi Nomor 69195/A2.3/KP/2017 tanggal 16 Mei 2017 (Ira, 2017).

Pada usia 75 tahun, Kamis 9 Agustus 2019 di Restoran Plataran Jakarta, Ma'ruf ditunjuk sebagai calon Wakil Presiden Republik Indonesia mendampingi Joko Widodo sebagai calon Presiden Indonesia pada pemilihan presiden tahun 2019.

Terpilihnya Ma'ruf Amin sebagai calon wakil presiden (cawapres) sebelumnya tidak pernah diprediksi. Nama Ma'ruf Amin menguat di detik-detik akhir Jokowi mengumumkan pasangan cawapresnya. Ada dua nama ketika itu, yakni Mahfud MD, mantan Ketua Mahkamah Konstitusi, dan Ma'ruf Amin (Sonny, 2019). Pada mulanya, banyak kalangan mengira Ma'ruf Amin tidak masuk sorotan Jokowi, karena ada pesaing dari kalangan militer yaitu Moeldoko, Kepala Staf Kepresidenan.

Ma'ruf Amin terpilih mendampingi Jokowi bukan tanpa alasan. Jokowi memberikan penjelasan Ma'ruf adalah tokoh agama yang bijaksana, pernah menjadi anggota legislatif DPRD, DPR, MPR, anggota Dewan Pertimbangan Presiden, Rais 'Aam PBNU dan Ketua Umum MUI (Januarius, 2018). 
Dalam kaitannya dengan kebhinekaan, Jokowi menegaskan Ma'ruf menjabat anggota Dewan Pengarah Badan Pembinaan Ideologi Pancasila (Januarius, 2018).

Dipilihnya Ma'ruf Amin sebagai pasangan Cawapres Jokowi memiliki tujuan untuk mempersempit ruang gerak radikalisme, ekstremisme, intoleransi, sektarianisme, dan rasisme di Indonesia yang berpenduduk mayoritas Muslim (Leo, 2018). Para analis politik mengomentari dan menyoroti kemunculan nama Ma'ruf Amin sebagai kandidat wakil presiden seperti misalnya M. Qodari dan Moch. Nurhasim (Leo, 2018).

M. Qodari, Direktur Eksekutif Lembaga Jajak Pendapat Indo Barometer menyebut pemilihan Mar'uf Amin sebagai cawapres Jokowi bukanlah kejutan besar mengingat Ma'ruf Amin selalu ada dalam daftar kandidat calon wakil presiden sejak awal (Leo, 2018). Dia mengatakan beberapa kriteria pemilihan calon wakil presiden mendampingi Joko Widodo, yaitu pertama, tidak berasal dari partai politik untuk mencegah timbulnya kecemburuan dari partai-partai politik dalam koalisi; kedua, harus dapat menjadi perwakilan untuk menanggapi berbagai macam isu yang berkaitan dengan suku, agama, ras, dan antargolongan (SARA).

Menurutnya, sosok yang mampu menanggapi problem SARA harus berasal dari lingkaran "hijau", bisa berasal dari kalangan ulama atau komunitas militer; ketiga, harus merupakan figur "senior", sebab jika calon wakil presiden relatif muda, dihawatirkan akan menjadi kandidat kuat untuk jabatan presiden pada Pemilu 2024; keempat, tidak ditolak oleh Megawati Soekarnoputri, Ketua Umum Partai Demokrasi Indonesia-Perjuangan, partai politik utama yang mengusung Joko Widodo; kelima, harus sesuai dengan gaya, model dan atau selera Jokowi (Leo, 2018).

Sementara itu Moch. Nurhasim, peneliti politik di Lembaga Ilmu Pengetahuan Indonesia menyatakan pemilihan Ma'ruf Amin sebagai calon wakil presiden untuk Jokowi, bertujuan untuk memelihara simpati dan dukungan politik dari komunitas Muslim. Hal ini dilakukan karena Prabowo Subianto diprediksi akan melakukan hal yang kurang lebih sama. Nurhasim menambahkan pertimbangan pragmatis bukan tanpa alasan. Tidak bisa dipungkiri setelah gerakan massa 212 oleh kelompok Islam konservatif, kekuatan politik komunitas Muslim telah berubah menjadi sebuah gerakan politik, dengan kekuatan yang luar biasa dalam memobilisasi pemilih (Leo, 2018).

Berdasarkan hal tersebut, Jokowi sebagai politisi tidak akan mengabaikan gerakan ini. Dengan demikian, Ma'ruf Amin dinominasikan sebagai cawapres Jokowi dimaksudkan untuk "mengekang" gerakan politik umat Islam sehingga tidak menjadi "liar" seperti yang terjadi dalam pemilihan Gubernur Jakarta tahun 2017. Sebuah pelajaran berharga bagi Tim Koalisi ketika Basuki Tjahaja Purnama gagal menjadi Gubernur DKI Jakarta padahal diusung koalisi partai besar yang mendukung Jokowi (Leo, 2018).

Pendapat berbeda disampaikan Pengamat Ekonomi Institute for Development of Economics and Finance (INDEF) Bhima Yudhistira yang mengungkapkan optimismenya. Dengan terpilihnya Ma'ruf Amin maka isu yang berkaitan dengan SARA dapat diredam. Menurutnya, Ma'ruf mampu menciptakan stabilitas politik (Bayu, 2018) sehingga tidak akan terjadi kegaduhan berlebihan ketika pertarungan Pilpres diisi dengan pertarungan konsep dan gagasan. Sisi positif lain, Ma'ruf Amin dianggap tokoh yang konsisten memperjuangkan konsep ekonomi Syariah yang bisa menjadi isi kampanye yang menarik (Bayu, 2018).

\section{Strategi Politik}

Setelah Ma'ruf Amin ditetapkan Komisi Pemilihan Umum pada 20 September 2018 sebagai cawapres mendampingi Jokowi, ia langsung mengundurkan diri dari jabatan Rais 'Aam PBNU, yang selanjutnya oleh rapat pimpinan PBNU, ia dimasukkan ke dalam jajaran Mustasyar bersama dengan K.H Maemoen Zubair (Sonny, 2019). Posisinya sebagai Rais 'Aam PBNU digantikan oleh Wakil Rais 'Aam PBNU K.H Miftachul Akhyar.

Langkah politik awal yang dilakukannya adalah mengonsolidasi kekuatan warga NU dengan melakukan kunjungan silaturahim sekaligus konsolidasi ke beberapa pondok pesantren, dengan harapan mampu mendulang suara dari pemilih warga NU. Konsolidasi dibungkus dengan kegiatan Halaqoh, dan silaturrahim Alim Ulama dan Kyai Pimpinan Pondok Pesantren. Ia menggunakan jajaran kepengurusan NU hingga tingkatan cabang yang mengakomodir pengurus di tingkatan kecamatan dan ranting (kelurahan) sebagai instrumen. Dengan demikian kegiatan konsolidasinya tidak perlu membangun jaringan baru, cukup mengandalkan jaringan NU dalam setiap safari politiknya. 
Langkah selanjutnya, Ma'ruf Amin memperluas jaringan dengan membentuk barisan pengawal. Salah satu putranya, Ahmad Syauqi Ma'ruf Amin atau akrab disapa Gus Syauqi, menginisiasi pembentukan Master C19 Portal KMA (Markas Terpadu Cirebon 19 Portal KH Mar'uf Amin), yaitu sebuah poros nyata laskar K.H Ma'ruf Amin (Sonny, 2019). Ma'ruf Amin sadar perjuangannya tidak cukup hanya di bawah bendera NU, sehingga organ taktis perlu dibentuk. Sebagai cawapres, harus menjadi milik semua kelompok.

Personel Master C19 Portal KMA bersepakat, kehadiran mereka tidak akan mengambil peran Tim Kampanye Nasional (TKN) pasangan 01 Jokowi-Ma'ruf Amin, tapi lebih pada membantu kerjakerja TKN (Sonny, 2019). Menurut Gus Syauqi, Master C19 Portal KMA adalah pengawal Ma'ruf Amin dalam menggarap simpul-simpul yang tidak terkover oleh TKN (Sonny, 2019).

Sebagai pengawal Ma'ruf Amin, Master C19 Portal KMA merumuskan tiga poin gerakan politik. Pertama mengawal gagasan Ma'ruf Amin yang mengusung "Arus Baru Ekonomi Indonesia”; kedua sebagai konsolidator media dengan memproduksi isu-isu di sosial media maupun di media mainstream dengan tujuan menyampaikan pesan pemikiran-pemikiran Ma'ruf Amin dengan cara menggelar diskusi publik, mematahkan isu-isu negatif yang diarahkan ke sosok Ma'ruf Amin; ketiga sebagai konsolidator relawan-relawan Ma'ruf Amin.

Master C19 Portal KMA memiliki peran pemikir dan operator lapangan. Dalam rangka mengembangkan simpul jaringan Master C19 Portal KMA mendesain gerakan yang diberi nama "Rembuk Simpul/Relawan KMA." Salah satu sasarannya mengonsolidasi kekuatan-kekuatan NU kultural, seperti jaringan kyai-kyai kampung yang menjalani tradisi amaliah NU (Ahlussunnah wal jamaah), kalangan millenial, kalangan minoritas-non Muslim, sebagai upaya memperluas jejaring (Sonny, 2019).

\section{Kampanye Islam Wasathiyah}

Untuk menarik suara potensial, Ma'ruf Amin mengkampanyekan Islam Wasathiyah (moderat) di dalam negeri dan di luar negeri. Islam Wasathiyah menurutnya, adalah sebuah model keislaman yang relevan dalam bingkai kenegaraan Indonesia (Muchlishon, 2018). Islam Washatiyah adalah sebuah bentuk peneguhan atas Islam yang cenderung moderat dan dianut oleh sebagian Muslim di Indonesia.

Ma'ruf menambahkan, Islam Wasathiyah penting untuk merespon berbagai penguatan dan konsolidasi paham-paham ekstremis atas nama Islam dalam beberapa tahun terakhir (Muchlishon, 2018). Ma'ruf menegaskan, Indonesia berpenduduk mayoritas Muslim, tetapi bukan negara agama. Indonesia juga bukan negara sekuler yang berusaha memisahkan agama dan negara. Sesuai dengan kesepakatan The Founding Fathers, dasar negara Indonesia adalah Pancasila (Muchlishon, 2018).

Pancasila dan Konstitusi Indonesia memuat prinsip-prinsip konsensus yang khas dalam mengelola relasi agama dan negara. Ma'ruf mengakui, perdebatan yang sangat panjang mengenai relasi antara agama dan negara di Indonesia. Ada kelompok yang menginginkan Indonesia menjadi negara Islam, dan kelompok yang ingin menjadikan Indonesia sebagai negara sosialis komunis. Ada juga kelompok yang tetap mempertahankan Indonesia sebagai negara bangsa berdasarkan Pancasila dan konsensus nasional. Perdebatan seperti itu pernah mengalami titik puncak dengan pecahnya pemberontakan yang dilakukan sebagian kelompok (Muchlishon, 2018).

Prinsip-prinsip Islam moderat telah berkembang di Indonesia sejak dahulu, bahkan sejak saat Islam dibawa oleh Wali Songo masuk ke Nusantara. Namun demikian, semangat Islam moderat (Wasathiyah) harus harus tetap diteguhkan mengingat paham-paham ekstrem yang mengatas namakan Islam semakin menjadi-jadi (Muhyiddin, 2019). Lebih kurang ada tiga model paham-paham ekstrem atas nama Islam, pertama, penggunakaan kekerasan seperti ISIS yang dideklarasikan pada 2014. ISIS melakukan aksi-aksi kekerasan dan perang demi menegakkan khilafah. Tidak hanya itu, mereka juga menyebut thaghut untuk negara yang sistemnya tidak berdasarkan Islam ala mereka; kedua, penggunaan cara damai/non-kekerasan, seperti Hizbut Tahrir, dan ketiga, terkadang menggunakan aksi kekerasan dan teror, seperti Jama'ah Islamiyah (Muhyiddin, 2019). Meski berbeda model dan aksi, namun kelompok-kelompok ekstremisme atas nama Islam itu sepakat untuk anti negara bangsa (nationstate) (Muhyiddin, 2019).

Pada kesempatan lain, dalam kampanye Ma'ruf menyatakan Islam Wasathiyah adalah Islam yang berpikir luas, tidak sempit/tekstual, dan juga terarah dan beraturan, tidak liberal. Selanjutnya, Islam juga bisa menyelesaikan persoalan-persoalan kebangsaan (Muhyiddin, 2019). Masih menurutnya, cara-cara kekerasan dalam menyelesaikan persoalan tidak diajarkan dalam Islam Wasathiyah. Selain itu Islam 
Wasathiyah juga tidak mengajarkan penggunaan cara-cara yang tidak terpuji untuk mewujudkan keinginannya seperti hoaks dan fitnah (Muhyiddin, 2019).

\section{Gagasan Arus Baru Ekonomi Indonesia}

Sebagai pendamping petahana Presiden Joko Widodo, Ma'ruf Amin melancarkan strateginya dengan memaparkan gagasan pembangunan ekonomi Indonesia. Gagasannya tersebut dilabeli dengan nama Arus Baru Ekonomi Indonesia (Rara, 2018), sebuah gagasan konseptual yang disertai dengan rekomendasi program yang kemudian dikenal dengan istilah Ma'rufnomics. Secara garis besar Ma'rufnomics menyandarkan kepada Sila ke-5 Pancasila yang diwujudkan dalam ekonomi kerakyatan dan berkeadilan sosial.

Penekanannya adalah mengurangi bahkan menghilangkan kesenjangan antarakaya dengan miskin, kuat dengan lemah, antardaerah dan antara produk lokal dengan global. Namun perlu menjadi catatan bahwa membangun yang lemah bukan berarti melemahkan yang kuat, terlebih dengan membenturkan yang lemah dengan yang kuat. Akan tetapi membangun yang lemah dengan menguatkan yang lemah dengan jalan kolaborasi kemitraan antara yang kuat dengan yang lemah, sehingga output yang didapat adalah kesejahteraan bagi seluruh rakyat (Rara, 2018).

Realitas yang ada dapat ditemukan dari proses penekanan terhadap persoalan ketimpangan ekonomi. Sebuah data menunjukkan kekayaan $50 \%$ penduduk Indonesia menurun dalam lima tahun terakhir, dari 3,8 \% total kekayaan nasional menjadi 2,8\%. Hal ini terlihat pula pada penguasaan $1 \%$ penduduk terkaya terhadap 45\% kekayaan nasional. Laporan Oxfam International 2017 dalam ilustrasinya menyebut, empat miliarder terkaya Indonesia memiliki kekayaan lebih dari gabungan 100 juta orang termiskin (Rara, 2018).

Oxfam juga mengungkap dalam 15 tahun terakhir telah terjadi konsentrasi kekayaan pada orangorang kaya di Indonesia. Sebagian besar kekayaan tersebut dihasilkan dari sumber daya alam seperti kelapa sawit, batu bara, dan mineral lainnya (Rara, 2018). Selain itu, kekayaannya juga diperoleh dari sektor keuangan, teknologi komunikasi, dan multimedia. Orang-orang kaya dimaksud telah menggabungkan kekayaan senilai 49,8 miliar dolar AS, sementara $84 \%$ penduduk Indonesia yang lain memiliki kekayaan kurang dari 10.000 dolar AS, sehingga tidak mengejutkan Credit Suisse pada 2016 menobatkan Indonesia sebagai negara yang memiliki ketimpangan pendapatan terburuk keenam dunia setelah Rusia, Denmark, India, Amerika, dan Thailand (Rara, 2018).

Mengenai istilah ekonomi umat, salah bila diartikan sebagai ekonomi milik umat Islam semata, karena sejatinya berbasiskan pada nilai universal. Umat yang dimaksud adalah seluruh umat beragama di Indonesia yang berbingkai Pancasila, UUD 1945, Bhinneka Tunggal Ika, dan Negara Kesatuan Republik Indonesia. Ketika ekonomi umat dikembangkan dalam bingkai umat Islam sebagai mayoritas, tidak berarti mengesampingkan umat minoritas lainnya. Dengan demikian, mengembangkan ekonomi umat berarti memberdayakan semuanya, titik beratnya terletak pada pemerataan, keadilan sosial, dan kepedulian dalam upaya memperkecil ketimpangan ekonomi.

Ekonomi umat dalam 30 tahun terakhir telah mengalami peningkatan yang cukup signifikan (Rara, 2018). Peningkatan tersebut tercermin dalam bentuk lembaga perbankan syariah dan telah diadaptasi oleh lembaga-lembaga keuangan lainnya seperti dalam sektor asuransi, pegadaian, bahkan pasar modal dan pasar komoditas yang berbasis syariah. Peningkatan terjadi tidak hanya dalam aset, namun juga dalam variasi produk, kesadaran, dan pemahaman terhadap keuangan syariah di kalangan pelaku industri dan masyarakat, serta kerangka regulasi yang relatif sudah lengkap dan komprehensif.

Menurut Ma'ruf Amin, salah satu terobosan dalam merevitalisasi ekonomi umat adalah disalurkannya kredit ultramikro oleh pemerintah. Terdapat anggaran Rp 1.500.000.000.000 berupa suntikan dana dari pemerintah bagi lapangan usaha pada level di bawah usaha mikro (ultramikro) yang tidak dijangkau oleh program kredit usaha rakyat (KUR). Evaluasi KUR yang ditemukan memiliki banyak kelemahan, kemudian dibentuklah kredit ultramikro.

Kelemahan KUR, salah satunya adalah penyalurannya menggunakan instrumen perbankan sehingga terjadi berbagai kerumitan persyaratan dan administrasi, sementara pelaku usaha mikro dan kecil hampir seluruhnya tidak memenuhi kriteria dan persyaratan perbankan, atau tidak layak kredit. Kredit ultramikro disalurkan tidak melalui lembaga keuangan bank, tetapi melalui koperasi, Balai Usaha Mandiri Terpadu atau Baitul Maal wa Tamwil (BMT), dan koperasi pesantren. 
Ma'ruf berharap dan mendorong agar NU, Muhammadiyah, dan lembaga-lembaga keumatan lainnya, mendapatkan porsi terbesar dalam penyaluran kredit ultramikro. Hal tersebut tertuang dalam rekomendasi Kongres Ekonomi Umat 2017 MUI di Jakarta pada April 2017 (Rara, 2018).

\section{Kemenangan Jokowi - Ma'ruf}

Komisi Pemilihan Umum menetapkan hasil akhir rekapitulasi penghitungan suara Pemilu 2019 baik Pemilihan Presiden (Pilpres) maupun Pemilihan Legislatif (Pileg). KPU menetapkan pasangan Jokowi - Maruf Amin meraih suara 55,50 persen atau 85.607.362 suara dan unggul di 21 propinsi: Gorontalo, Kalimantan Tengah, Kalimantan Utara, Kalimantan Barat, Bangka Belitung, Bali, Sulawesi Barat, Yogyakarta, Kalimantan Timur, Lampung, Sulawesi Utara, Sulawesi Tengah, Jawa Timur, NTT, Jawa Tengah, Kepulauan Riau, Papua Barat, DKI Jakarta, Sumatera Utara, Maluku, dan Papua.

Meskipun hasil Pilpres 2019 sempat menjadi sengketa, dan pasangan calon presiden Prabowo Subianto - Sandiaga Uno mengajukan gugatan ke Mahkamah Konstitusi (MA), namun pada akhirnya MA menolak seluruh permohonan yang diajukan, sehingga secara hukum pasangan calon presiden Joko Widodo dan Ma'ruf Amin sah menjadi pemenang Pilpres 2019. Selanjutnya Joko Widodo-Ma'ruf Amin dilantik pada 20 Oktober 2019 sebagai Presiden dan Wakil Presiden RI periode 2019-2024.

Kemenangan yang diraih pada kontestasi demokrasi pilpres 2019 perlu mendapat catatan. Konsolidasi Ma'ruf Amin pada Nahdlatul Ulama memang sangat diperlukan. Peneliti tidak menemukan data yang menyatakan Ma'ruf Amin melakukan konsolidasi pada organisasi lain di luar NU, padahal itu sebenarnya juga dibutuhkan. Sungguh ironi, Agustus 2018 Ma'ruf Amin ditunjuk sebagai Calon Wakil Presiden Republik, pada September 2019 keluar Surat Keputusan Ijtima Ulama dan Tokoh Nasional II tentang Pakta Integritas Calon Presiden dan Wakil Presiden yang pada intinya mendukung pencapresan Prabowo Subianto dan Sandiaga Uno.

Secara cerdik Capres Prabowo dan Cawapres Sandiaga Uno mengambil celah emosi publik dan kelompok muslim menengah. Sebagaimana pengkategorian kelompok muslim menengah yang banyak diprakarsai oleh kelompok FPI dan GNPF; kelompok tersebut cenderung lekat dengan kategorisasi santri neo-revivalis (Fata, 2019). Kelompok ini mengusung semangat mengembalikan kerangka sosial, ekonomi, dan agama pada dasar-dasar agama. Kelompok tersebut, lengkap dengan gerakan-gerakan masanya, mempraktikkan populisme seperti hendak 'memeluk' demokrasi seraya mendesak rezim yang berkuasa agar mengakomodasi kepentingan politik mereka (Fata, 2019).

Fenomena ini terbukti dengan kedekatan kelompok neo-revivalis dengan kubu Prabowo-Sandi. Misalnya saja, penerimaan kubu Prabowo atas Ijtima' Ulama GNPF dalam memilih wakil presiden. Mulanya, hasil ijtima sangat jelas mengantarkan perwakilan-perwakilan kelompok revivalis menjadi wakil dari calon presiden. Hasilnya, ulama-ulama seperti Abdul Somad dan Salim Segaf Al-Jufri yang lebih dekat dengan kategori Islam konservatif diajukan menjadi calon wakil presiden dalam pemilu 2019. Walupun hasil akhir berlainan, kelompok revivalis ini tetap berada di kubu Prabowo-Sandiaga.

Kelompok yang selalu berhadapan dengan negara ini mendapatkan momentumnya dalam gerakan masal 212 pada 2 Desember 2018. Kelompok ini terus didukung dalam bentuk kampanye 'damai' oleh Prabowo-Sandi, misal peresmian Gerakan Indonesia Sholat Subuh (GISS) dan reuni 212. Bentuk dukungan oleh ulama-ulama kemudian selalu dirujuk untuk calon presiden dan wakil presiden sesuai dengan ijtihad mereka: Prabowo-Sandi. Pasangan capres-cawapres tersebut turut mengambil untung dari gerakan massa yang telah terbukti mampu memobilisasi kalangan santri. Tidak hanya kelompok revivalis yang diwakili oleh PKS, juga kelompok NU yang turut serta dalam pengawalan fatwa ulama.

\section{KESIMPULAN}

Personal branding Ma'ruf Amin sebagai tokoh Islam di satu sisi belum mampu menarik simpati di hadapan branding partisipasi politik 212 namun dapat mendulang keberhasilan dalam Kontestasi Demokrasi Pilpres 2019 di Indonesia pada sisi lainnya. Dengan demikian, secara hitung-hitungan matematis Ma'ruf Amin memang menang, tetapi tanggung jawab seorang ulama, menurut peneliti kalah dan berhutang. Polarisasi yang ada di tubuh umat Muslim baik pada warga NU kultural maupun struktural, dan pada seluruh jamaah muslim di tanah air, harusnya bisa dilakukan depolarisasi, dikembalikan seperti sebelumnya tanpa ada polarisasi.

\section{DAFTAR PUSTAKA}

Abdullah, A. (2017). Membaca Komunikasi Politik Gerakan Aksi Bela Islam 212: Antara Politik 
Identitas dan Ijtihad Politik Alternatif. An-Nida: Jurnal Pemikiran Islam, 41(2), 202-212. Retrieved from http://ejournal.uin-suska.ac.id/index.php/Anida/article/view/4654

Ahmad, R. K. (2017). Viral, Masjid Ini Tolak Salatkan Jenazah Pembela Penista Agama. News.Detik.Com.

Alwi, D. (1990). Perkembangan Komunikasi Politik Sebagai Bidang Kajian. Jurnal Ilmu Politik, 6.

Anwar, F. A. (2018). Notes on 212 in 2018: More Politics, Less Unity. Www.Newmandala.Org.

Arya, F. (2018). Politik Identitas dalam Pemilu 2019: Proyeksi dan Efektivitas. Centre for Strategic and International Studies, (1).

Bayu, K. M. R. (2018, August). Jokowi Tunjuk Ma'ruf Amin Jadi Cawapres, Ini Prediksi Pengamat Ekonomi. Www.Liputan6.Com.

Bennett, W. L. (2012). The Personalization of Politics: Political Identity, Social Media, and Changing Patterns of Participation. Annuals of the American Academy of Political and Social Science, 644(1), 20-39. https://doi.org/10.1177/0002716212451428

Bernardez. (2007). A New Blueprint for Powerful and Authentic Personal Branding. Performance Improvement, 47(6), 34-37. https://doi.org/10.1002/pfi

Caulfield, S. (2005). The Policing of Public Spaces. (May 2018), 1-20. https://doi.org/10.1093/oxfordhb/9780199843886.013.010

Crozier, M. (2007). Recursive Governance: Contemporary Political Communication and Public Policy. Political Communication, 24(1), 1-18. https://doi.org/10.1080/10584600601128382

Fata, M. K. (2019). Membaca Polarisasi Santri dalam Kontestasi Pilpres 2019. Pusham, 18(November 2018), 325-344.

Felicia, F. F. (2018). Kiai Ma'ruf Amin: Dulu Saya yang Menggerakkan Aksi 212. Www.Jawapos.Com.

Friedkin, N. E. (1999). Choice Shift and Group Polarization. American Sociological Review, 64(6), 856-875. https://doi.org/10.2307/2657407

Hughes, A. (2007). Personal Brands: An Exploratory Analysis of Personal Brands in Australian Political Marketing. Advertising Research, (at 309), 1114-1120.

Ira. (2017). K.H. Ma'ruf Amin Dikukuhkan Menjadi Guru Besar Ilmu Ekonomi Muamalat Syariah. Http://Sumberdaya.Ristekdikti.Go.Id.

Isfahani, A. N., Aghdaie, S. F. A., \& Homaei, R. (2011). Manager' s Personal Brands ( MPB ): The Secret of Success or Failure. International Journal of Business and Social Science, 2(20), 281286.

Januarius, K. F. (2018, August). Ini Alasan Jokowi Pilih Ma'ruf Amin Jadi Cawapresnya. Kompas. Com. Johnson, K. M. (2017). The Importance of Personal Branding in Social Media: Educating Students to Create and Manage their Personal Brand. Int. J. Educ. Soc. Sci, 4(1), 7.

Katie, G. (2019). Donald Trump: Why White Evangelical Women Support Him. Theconversation.Com.

Kerr, N. L. (1992). 'Issue Importance and Group Decision Making', in S. Worchel, W. Wood and J. Simpson (eds.), Group Process and Productivity. In Sage Publications. Newbury Park.

Lemonjake. (2019). Kiai Ma'ruf: Pencetus Dewan Syariah Nasional dan Fatwa-Fatwanya. Www.Kompasiana.Com.

Leo, J. (2018, August). Alasan di Balik Pencalonan Ma'ruf Amin sebagai Cawapres Jokowi. Matamatapolitik.Com.

Marsh, D., \& Fawcett, P. (2011). Branding, politics, and democracy. Routledge: Taylor \& Francis, 32(5), 515-530. https://doi.org/10.1080/01442872.2011.586498

McGarty, C., Turner, J. C., Hogg, M. A., David, B., \& Wetherell, M. S. (1992). Group Polarization as Conformity to the Prototypical Group Member. British Journal of Social Psychology, 31(1), 119. https://doi.org/10.1111/j.2044-8309.1992.tb00952.x

McNair, B. (2011). An Introduction to Political Communication: Sixth edition. In Routledge: Taylor \& Francis (5th ed.). https://doi.org/10.4324/9781315750293

Miller, J. L., \& McKerrow, R. E. (2010). History of Political Communication. Review of Communication, 10(1), 61-74. https://doi.org/10.1080/15358590903370233

Muchlishon. (2018). Di Singapura, K.H Ma'ruf Amin Sampaikan Urgensi Islam Wasathiyah. $N U$ Online.

Muhyiddin. (2019). Kiai Ma'ruf Sebut Islam Wasathiyah Bisa Jadi Solusi. Republika.Co.Id.

Needham, C., \& Smith, G. (2015). Introduction: Political Branding. Journal of Political Marketing, 14(1-2), 1-6. https://doi.org/10.1080/15377857.2014.990828 
Nimmo Dan, Rakhmat, J., \& Surjaman, T. (2005). Political Communication and Public Opinion in America/Komunikasi Politik: Komunikator, Pesan, dan Media (6th ed.). Bandung: Remaja Rosdakarya.

Rara, P. (2018, September). Ma'ruf Amin dan Arus Baru Ekonomi Indonesia. Detiknews.

Redaksi, K. (2018). Berusia 75 Tahun, Ma'ruf Amin Jadi Cawapres Tertua. Kumparan.Com.

Reuni 212: Relevansi Gerakan dan Upaya Menggenjot Suara Prabowo. (2018). Www.Bbc.Com.

Sari, E. (2016). Kebangkitan Politik Identitas Islam Pada Arena Pemilihan Gubernur Jakarta. Kritis: Jurnal Ilmu Sosial Dan Ilmu Politik Universitas Hasanuddin, 2(2), 145-156. Retrieved from http://journal.unhas.ac.id/index.php/kritis/article/view/4164

Sonny. (2019). Nilai Strategis Kefiguran KH Ma'ruf Amin sebagai Pasangan Joko Widodo pada Pemilihan Presiden 2019. Jurnal Renaissance, 4(02), 541-550. Retrieved from $\mathrm{http} / / /$ www.ejournal-academia.org/index.php/renaissance NILAI

Syafii, M. A. (2010). Politik identitas dan Masa Depan Pluralisme Kita (I; M. Husni, ed.). Jakarta: Pusat Studi Agama dan Demokrasi (PUSAD) Yayasan Wakaf Paramadina.

Ubed, A. S. (2002). Politik Identitas Etnis: Pergulatan Tanda Tanpa Identitas (1st ed.). Magelang: Indonesiatera.

Wink. (2018). Biografi KH Ma'ruf Amin - Profil dan Biodata Lengkap Ulama Indonesia.

Zaenal, M. (2012). Senat Akademik Sepakat Anugerahkan Dr. HC kepada KH Ma'ruf Amin. BERITA UIN Online. 